\title{
Macronutrient Composition of Selected Traditional Yams Grown in Sri Lanka
}

\author{
W.M.A.A. Kulasinghe, K.M.S. Wimalasiri ${ }^{1}$, G. Samarasinghe ${ }^{2}$, R. Silva ${ }^{3}$ and T. Madhujith ${ }^{1 *}$ \\ Postgraduate Institute of Agriculture \\ University of Peradeniya \\ Sri Lanka
}

\begin{abstract}
A study was carried out to determine the moisture content, crude fat, crude protein, ash content, total carbohydrate content, and some mineral elements namely, $M g, K$, $\mathrm{Ca}, \mathrm{Al}, \mathrm{Cr}, \mathrm{Mn}, \mathrm{Fe}, \mathrm{Co}, \mathrm{Ni}, \mathrm{Cu}, \mathrm{Zn}, \mathrm{As}, \mathrm{Se}, \mathrm{Sn}, \mathrm{Pb}, \mathrm{Li}, \mathrm{Be}, \mathrm{V}, \mathrm{Ga}, \mathrm{Rb}, \mathrm{Sr}, \mathrm{Mo}, \mathrm{Cd}$ and $\mathrm{Ba}$ of yams grown in Sri Lanka. Oven dried powders of Dioscorea pentaphylla (Katuala), D. alata (Rajala and Angiliala) and D. esculenta (Kukulala) were subjected to analysis. Samples were collected representing all the agro-climatic zones in Sri Lanka according to the availability. Moisture and total carbohydrate contents of selected yams ranged from 62.61 to $73.15 \%$ and 18.30 to $26.84 \%$, respectively, with no significant variations among species $(P>0.05)$. The crude fat content of yams ranged from 0.18 to $0.06 \%$ in the tested yams while Kukulala contained the highest crude fat content. Crude protein levels ranged from 1.30 to $1.91 \%$ where Rajala showed the highest level. The ash content varied between 0.64 and 0.84 $\%$ with the highest quantity in Angiliala. $\mathrm{K}, \mathrm{Mg}, \mathrm{Na}, \mathrm{Zn}$ and $\mathrm{Fe}$ were the most abundant mineral elements in tested yams where potassium showed the highest availability (4.61 to $5.12 \mathrm{mg} / \mathrm{g}$ ). Significant differences of crude fat, crude protein, ash and most of the mineral contents were observed among different accessions of the same species.
\end{abstract}

Keywords: Agro-climatic zones, mineral composition, nutritional composition, underutilized yams

\section{INTRODUCTION}

Dioscorea (Family: Dioscoreaceae) is the genus consisting of 630 species of which nearly 40 Dioscorea varieties are grown in Sri Lanka (Jayasuriya, 1995). Yams and tuber crops that can be cultivated under less favorable conditions with minimum amount of agricultural inputs are good sources of starch. These crops are grown in the tropical regions and consumed as primary, secondary or supplementary staple. Yams and tuber crops can be eaten boiled, roasted, fried or cooked. Dioscorea alata and D. esculenta are the two main yam species commonly grow in Sri Lanka (Senanayake et al., 2012).

Based on mean annual rainfall, Sri Lanka has three climatic zones: wet $(>2500 \mathrm{~mm}$ mean annual rainfall), intermediate $(1750-2500 \mathrm{~mm}$ mean annual rainfall) and dry zone $(<1750$ mm mean annual rainfall) (Punyawardena et al., 2003). Department of Agriculture

\footnotetext{
1 Department of Food Science and Technology, Faculty of Agriculture, University of Peradeniya, Sri Lanka

2 Plant Genetic Resource Center, Gannoruwa, Sri Lanka

3 Department of Applied Nutrition, Faculty of Livestock, Fisheries and Nutrition, Wayamba University of Sri Lanka, Sri Lanka

* Corresponding author: madujith@yahoo.com
} 
recommends the cultivation of Dioscorea species in all three climatic zones, due to the high adaptability of this crop, the availability of suitable species and low management requirements when compared to other crops such as vegetables and cereals (Ray and Sivakumar, 2009). However, there is no comparative report available for Sri Lanka on farmers growing these species in different climatic zones and the practices they adopt to cultivate Dioscorea (Sangakkara and Frossard, 2014).

Kukulala (D. esculenta) is widely cultivated in Sri Lanka due to its flavor and short maturity period. The fleshy underground stem of D. alata (Rajala and Hingurala) contains only a single large tuber per vine. Dioscorea are seasonal crops and generally planted at the end of March to April. With the signs of yellowing leaves and withered vines, the mature crop is usually ready to harvest in December to February (Senanayake et al., 2012). Starch is the main component in the yams (60 - 85\% dry basis) and forms an important component in the diet of population living in rural areas of Sri Lanka. Efficient supply of nutrients (both macro- and micronutrients) in the human diet is essential in maintaining the healthy lifestyle (Jayakody et al., 2007). This study was carried out to assess the nutritional composition of crude flours of D. pentaphylla (Katuala), D. alata (Rajala and Angili ala) and D. esculenta (kukulala) grown in Sri Lanka and to investigate the availability of some macronutrients and minerals.

\section{Chemicals}

\section{MATERIALS AND METHODS}

Chemicals, $\mathrm{H}_{2} \mathrm{SO}_{4}$ (96\%), $\mathrm{NaOH}$, boric acid (99\%), Bromocrysol green (analytical grade), petroleum ether $\left(40-60{ }^{\circ} \mathrm{C}\right.$, analytical grade), $\mathrm{HCl}(95 \%)$, sodium carbonate $(99 \%)$, phenol (100\%), nitric acid (99.9\%) were purchased from Sigma Adrich, Missouri, United States.

\section{Sampling plan and sample collection}

Four Dioscorea types namely, D. pentaphylla (Katuala), D. alata (Rajala and Angili ala) and D. esculenta (kukulala) were collected from the research stations of the Department of Agriculture as well as from selected farmer fields from dry, wet and intermediate zones to represent climatic variation. One germplasm sample from Plant Genetic Resources Center, Gannoruwa, Sri Lanka was also acquired. All the samples from each variety from each agroclimatic zone were collected during the last six months of the year 2016 (Plate 1).

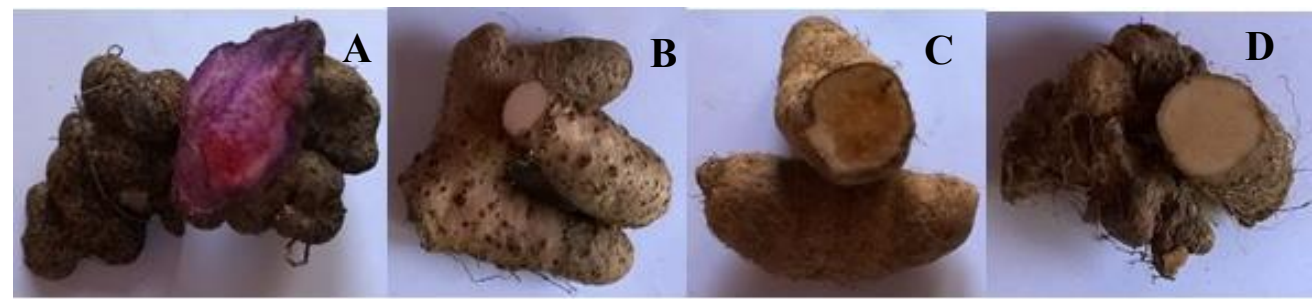

Plate 1: A-Rajala (Dioscorea alata), B-Angili ala (Dioscorea alata), C-Kukulala (Dioscorea esculenta), D-Katu ala (Dioscorea pentaphylla) 


\section{Preparation of yam samples}

A total of $500 \mathrm{~g}$ of healthy, undamaged edible parts of each yam sample were collected, sealed in polythene bags separately, labeled, placed in temperature controlled containers and transported to the laboratory without delay. Once the samples were received, they were photographed, cleaned, air dried, disintegrated separately to prepare the composite sample. Disintegrated yam samples were oven dried (Phoenix, Germany) at $40-45{ }^{\circ} \mathrm{C}$. Dried yam samples were powdered using a grinder (Apex, India) and stored at $5{ }^{\circ} \mathrm{C}$. After grinding, equal amounts of samples received from each agro-climatic zone were pooled and homogenized to obtain a composite sample. Moisture contents of pooled samples were analyzed.

\section{Analysis of yam samples}

The Table 1 lists the constituents analyzed for and methods used. All samples were analyzed in triplicate and if the coefficient of variance was over $15 \%$ the test/s were repeated.

\section{Table 1. Constituents analyzed and the methods adopted}

\begin{tabular}{|c|c|}
\hline Constituent & Method \\
\hline Moisture content & Gravimetric method - AOAC 925:40:2000 \\
\hline Protein content & $\begin{array}{l}\text { Kjeldhal digestion, titrimetric using } \\
\text { conversion factor - AOAC 920:87:2009 }\end{array}$ \\
\hline Crude fat content & Soxhlet method - AOAC, 920.39C:2000 \\
\hline Ash content & Gravimetric method - AOAC 923.03:2000 \\
\hline Total carbohydrate content & Phenol - Sulfuric method- (Bartkiene, 2012) \\
\hline $\begin{array}{l}\text { Minerals }(\mathrm{Mg}, \mathrm{K}, \mathrm{Ca}, \mathrm{Al}, \mathrm{Cr} \text {, } \\
\mathrm{Mn}, \mathrm{Fe}, \mathrm{Co}, \mathrm{Ni}, \mathrm{Cu}, \mathrm{Zn}, \mathrm{As}, \\
\mathrm{Se}, \mathrm{Sn}, \mathrm{Pb}, \mathrm{Li}, \mathrm{Be}, \mathrm{V}, \mathrm{Ga}, \mathrm{Rb}, \\
\mathrm{Sr}, \mathrm{Mo}, \mathrm{Cd}, \mathrm{Be})\end{array}$ & $\begin{array}{l}\text { Inductively Coupled Plasma Mass Spectrometry (ICP- } \\
\text { MS) method - (Ying, Liu and Ji, 2007); (Hongxing and } \\
\text { Yu-kui, 2012) }\end{array}$ \\
\hline
\end{tabular}

\section{Analysis for proximate composition}

Moisture content was determined according to AOAC 925:40:2000 method. Known amount of fresh yams samples were dried at $105{ }^{\circ} \mathrm{C}$ until weight of the samples become constant using a continuous airflow oven (Sibata-SPF 600, Japan). Moisture content of the samples was calculated by measuring the cooled samples to room temperature using a top loading balance (Kern-ABJ 320-4NM, Germany).

Kjeldhal method was used to measure the crude protein content of oven dried yam samples (AOAC 920:87:2000). Dried yam samples were digested with $20 \mathrm{~mL}$ of Conc. $\mathrm{H}_{2} \mathrm{SO}_{4}$ acid (Velp Scientifica-DK 6, Italy) at $450{ }^{\circ} \mathrm{C}$ for $30 \mathrm{~min}$. The content of the Kjeldhal tube was diluted with $25 \mathrm{~mL}$ distilled water added along the wall of the tubes.

Distillation was carried out in the presence of $40 \% \mathrm{NaOH}$ in distillation unit (Velp Scientifica-UDK 129, Italy) and ammonia liberated from the digests was trapped in boric acid. The contents in the receiving flasks were titrated against $0.1 \mathrm{~N}$ hydrochloric acid in the presence of Bromocrysol green as the indicator and the protein content of the samples was calculated. 
Crude fat content was determined according to AOAC 920.39C:2000 method. Weighed samples were placed in cellulose extraction thimbles and transferred into Soxhlet tubes. Fat extraction was carried out with petroleum ether $\left(40-60{ }^{\circ} \mathrm{C}\right.$, analytical grade). Solvent was removed by evaporating on a rotavapor (Sibata-C302, Japan). Crude fat content was determined using the weights of the extracted fat.

Ash content of the samples was determined using AOAC 923.03:2000 method. Accurately weighed oven dried samples were charred directly over a Bunsen burner and kept in the Muffle furnace (Hobersal, Spain) at $550{ }^{\circ} \mathrm{C}$ overnight. The samples were weighed and the ash content was calculated.

\section{Quantification of total carbohydrate content}

Known amounts of oven dried samples were hydrolyzed by on a boiling water bath for $3 \mathrm{~h}$ with $2.5 \mathrm{~mL}$ of $2.5 \mathrm{~N} \mathrm{HCl}$. The hydrolyzed samples were neutralized with sodium carbonate until effervescences ceased. Resulting solutions were brought up to $50 \mathrm{~mL}$ with distilled water, centrifuged (Hitachi-Himac CT 4D, Japan) at $4000 \mathrm{rpm}$ for $10 \mathrm{~min}$. Supernatants were collected and aliquots of $0.1-0.2 \mathrm{~mL}$ were drawn for analysis. One $\mathrm{mL}$ of $5 \%$ phenol and 5 $\mathrm{mL}$ of $96 \%$ sulphuric acid were added into each tube and mixed well. After $10 \mathrm{~min}$, the contents were kept in a water bath at $25-30{ }^{\circ} \mathrm{C}$ for $20 \mathrm{~min}$. The color was measured at 490 $\mathrm{nm}$ using a UV visible spectrophotometer (Thermo Scientific-Genesys 10S, UK). The amounts of total carbohydrates present in samples were calculated using a standard graph generated using a series of standard glucose (Bartkiene, 2012).

\section{Quantification of minerals using Inductive Couple Plasma Mass Spectrometer (ICP- MS)}

A sample of oven-dried yam samples $(0.5 \mathrm{~g})$ was mixed with $10 \mathrm{~mL}$ of conc. nitric acid and digested with MARS 6 microwave digester. The samples were digested for 15 min (predigestion) with a 1 hour of total run time. Blank sample was digested using the same digestion procedure devoid of any sample. Once the digestion process was over, the samples were filtered and the volume was made up to $50 \mathrm{~mL}$ with deionized water. Digested samples were stored under frozen conditions (SISIL- IFC142LXX, Sri Lanka) at $-20{ }^{\circ} \mathrm{C}$.

Samples were analyzed using ICP-MS (Thermo Scientific-iCAPQ, UK) equipped with an auto-sampler (CETAC ASX-560), for $\mathrm{Na}, \mathrm{Mg}, \mathrm{K}, \mathrm{Ca}, \mathrm{Al}, \mathrm{Cr}, \mathrm{Mn}, \mathrm{Fe}, \mathrm{Co}, \mathrm{Ni}, \mathrm{Cu}, \mathrm{Zn}, \mathrm{As}$, $\mathrm{Se}, \mathrm{Sn}, \mathrm{Li}, \mathrm{Be}, \mathrm{V}, \mathrm{Ga}, \mathrm{Rb}, \mathrm{Sr}, \mathrm{Mo}, \mathrm{Cd}, \mathrm{Ba}$ and $\mathrm{Bi}$ under following operation conditions. Samples were analyzed using $1550 \mathrm{~W}$ plasma power, $14 \mathrm{~L} \mathrm{~min}^{-1}$ of cool gas flow, $0.65 \mathrm{~L}$ $\mathrm{min}^{-1}$ of auxiliary gas flow, $10 \mathrm{~ms}\left(40 \mathrm{~ms}\right.$ for Se, As) dwell time and $0.4 \mathrm{~mL} \mathrm{~min}{ }^{-1}$ of sample flow rate. TM 25.4 (Environment Canada) for water reference was used to determine the accuracy of the analysis. Standards were used to develop standard curves for each mineral. $\mathrm{Rh}$ and Re were used as internal standards at $100 \mathrm{ppb}$ level. Mineral contents were calculated using absorbance (Ying, Liu and Ji 2007; Hongxing and Yu-kui 2012).

\section{Statistical analysis}

One-way analysis of variance was carried out on the experimental results using the species as an independent variable. The significance of differences between means was compared by Tukey's Multiple Comparisons Procedure. All calculations were performed using SAS 9 statistical software. 


\section{RESULTS AND DISCUSSION}

\section{Proximate composition of yams}

The proximate composition of the analyzed varieties of yams is presented in Table 2. The results were comparable with the data reported by Knoth (1993). The results indicated that Katuala (D. pentaphylla) contained the highest moisture content of $73.15 \pm 10.64 \%$ while Kukulala (D. esculenta) had the lowest moisture content $(62.61 \pm 7.65 \%)$. Both Rajala $(D$. alata) and Angili ala (D. alata) contained approximately equal moisture contents $(66.54 \pm 6.81 \%$ and $65.53 \pm 9.38 \%$, respectively). There were no significant difference in moisture content of all four Dioscorea spp analyzed ( $P>0.05)$. Polycarp et al. (2012) have concluded that the moisture content of the fresh tubers ranges between $58.18 \%$ to $77.79 \%$ and the varieties could be grouped into three categories according to their dry matter content. Both Rajala (D. alata) and Katuala (D. pentaphylla) possessed equal amounts of crude fat of $0.06 \%$, while Kukulala (D. esculenta) contained the highest crude fat content of $0.18 \pm 0.02 \%$. The least crude fat content $(0.11 \pm 0.008 \%)$ was observed in Angili ala (D. alata).

The highest crude protein content $(1.91 \pm 0.06 \%)$ was observed in Rajala (D. alata) followed by Katuala (D. pentaphylla). Both Kukulala (D. esculenta) and Angili ala (D. alata) contained approximately similar crude protein contents. The results show that Rajala and Angili ala possess different crude protein contents although both yams belong to the same species and variety. Baah et al. (2009) have studied 16 varieties of D. alata and proved that the protein content of $D$. alata species can vary from $4.2 \%$ to $8.7 \%$ on dry weight basis. Angili ala (D. alata) possessed the highest ash content of $0.84 \pm 0.05 \%$ while Rajala $(D$. alata) contained the least content of ash $(0.64 \pm 0.15 \%)$. Katuala (D. pentaphylla) had the second highest ash content of $0.76 \pm 0.003 \%$ while Kukulala (D. esculenta) contained $0.65 \pm 0.01 \%$ ash. Lebot et al. (2005) reported that $D$. alata species possess ash content of 2.50-4.90\%. According to Osagie (1992), the amount of ash in a tuber depends on the type of soil where they have been grown in, the moisture content and the maturity of the crop.

All yams tested contained the same amount of total carbohydrates $(P<0.05)$. Kukulala $(D$. esculenta) had the highest total carbohydrate content of $26.84 \pm 0.94 \%$ while Katuala $(D$. pentaphylla) contained the least total carbohydrate content $(18.30 \pm 0.21 \%)$. Both Rajala (D. alata) and Angili ala (D. alata) contained approximately equal amounts of total carbohydrates $(23.48 \%$ to $24.02 \%)$. The starch content of tubers ranged between $60.3 \%$ and 74.4\% according to Baah et al. (2009). Moorthy (1994) and Yu and Izidorczyk (2002) have shown that starch accounts for about $80 \%$ on dry weight basis of carbohydrate and, it is also a dominant factor in determining the physicochemical, rheological and textural characteristics of yam food products (Table 2).

Table 2. Proximate composition (percentage) of selected yams

\begin{tabular}{lccccc}
\hline Crop & Moisture & Crude Fat & $\begin{array}{c}\text { Crude } \\
\text { Protein }\end{array}$ & Ash & $\begin{array}{c}\text { Total } \\
\text { Carbohydrate }\end{array}$ \\
\hline $\begin{array}{l}\text { Rajala }(\text { D. alata }) \\
\begin{array}{l}\text { Kukulala }(D . \\
\text { esculenta) }\end{array}\end{array}$ & $66.54 \pm 0.81^{\mathrm{a}}$ & $0.06 \pm 0.02^{\mathrm{a}}$ & $1.91 \pm 0.06^{\mathrm{a}}$ & $0.64 \pm 0.15^{\mathrm{a}}$ & $23.48 \pm 0.32^{\mathrm{a}}$ \\
$\begin{array}{l}\text { Katuala }(\text { D. } \\
\text { pentaphylla })\end{array}$ & $73.15 \pm 0.64^{\mathrm{a}}$ & $0.06 \pm 0.02^{\mathrm{a}}$ & $1.65 \pm 0.09^{\mathrm{b}}$ & $0.76 \pm 0.003^{\mathrm{ab}}$ & $18.30 \pm 0.21^{\mathrm{a}}$ \\
$\begin{array}{l}\text { Angili Ala }(D . \\
\text { alata) }\end{array}$ & $65.53 \pm 0.38^{\mathrm{a}}$ & $0.11 \pm 0.008^{\mathrm{b}}$ & $1.34 \pm 0.06^{\mathrm{b}}$ & $0.84 \pm 0.05^{\mathrm{b}}$ & $24.02 \pm 0.32^{\mathrm{a}}$ \\
\hline
\end{tabular}

Data represent the mean of three replicates fresh weight basis. Values followed by the different superscript in each column are significantly different $(P<0.05)$ 
Results reported in this study are comparable with the findings of Treche and Agbor-Egbe, (1995); Afoakwa and Sefa-Dedeh, (2001); Shanthakumari et al. (2008). They have identified protein, fat and ash content of Dioscorea species are low with only 3-11\%, 0.05-2.5\% and $3-$ $9 \%$ respectively on dry weight basis.

\section{Mineral contents of yams}

Table 3 shows the mineral content of yams studied. Comparison of mean values per species for each mineral estimated showed that significant differences $(P<0.05)$ exist among yam species. All yam species analyzed were rich in potassium. Rajala (D. alata) contained the highest potassium level of $5120 \pm 0.22 \mu \mathrm{g} / \mathrm{g}$. Katuala (D. pentaphylla) $(4610 \pm 1.34 \mu \mathrm{g} / \mathrm{g}$ ) and Rajala (D. alata) possessed significantly same amounts of potassium levels. Angili ala (D. alata) and Kukulala (D. esculenta) contained $4750 \pm 0.49 \mu \mathrm{g} / \mathrm{g}$ and $4900 \pm 0.24 \mu \mathrm{g} / \mathrm{g}$ of potassium contents respectively. Senanayake et al. (2012) described that this may due to high availability of potassium in the soil where they have been grown. Bhandari, Kasai and Kawabata (2003) reported 250-560 mg/100 g potassium in Dioscorea species on fresh weight bases that can verify these findings.

Dioscorea species are rich in magnesium and sodium as well. Kukulala (D. esculenta) contained the highest magnesium level $(280 \pm 0.02 \mu \mathrm{g} / \mathrm{g})$ while Angili ala (D. alata) contained the highest sodium content $(260 \pm 0.001 \mu \mathrm{g} / \mathrm{g})$. Magnesium content of Rajala (D. alata), Katuala (D. pentaphylla) and Angili ala (D. alata) ranged from $170 \mu \mathrm{g} / \mathrm{g}$ to $250 \mu \mathrm{g} / \mathrm{g}$ while magnesium level of Katuala (D. pentaphylla) was significantly $(P<0.05)$ different from Rajala (D. alata) and Angili ala (D. alata). Sodium content of Rajala (D. alata) $(40 \pm 0.004$ $\mu \mathrm{g} / \mathrm{g})$ and Katuala $(D$. pentaphylla $)(30 \pm 0.003 \mu \mathrm{g} / \mathrm{g})$ was significantly $(P<0.05)$ different from those of Kukulala (D. esculenta) $(20 \pm 0.002 \mu \mathrm{g} / \mathrm{g})$.

Considering microelements, iron and zinc were abundant in yams. Iron content of yams ranged from $16.80 \mu \mathrm{g} / \mathrm{g}$ to $26.99 \mu \mathrm{g} / \mathrm{g}$. The highest zinc level was found in Katuala (D. pentaphylla) $(37.58 \pm 0.26 \mu \mathrm{g} / \mathrm{g})$ while the lowest zinc content of $9.82 \pm 1.90 \mu \mathrm{g} / \mathrm{g}$ was found in Angili ala (D. alata). Instead of iron and zinc, rubidium also found in higher levels in the yams tested. Significantly $(P<0.05)$ high rubidium levels were found in Rajala (D. alata) $(15.47 \pm 0.02 \mu \mathrm{g} / \mathrm{g})$ and Kukulala (D. esculenta) $(15.46 \pm 0.48 \mu \mathrm{g} / \mathrm{g})$.

Aluminum content of Rajala (D. alata) and Kukulala (D. esculenta) ranged between 5.85 $\mu \mathrm{g} / \mathrm{g}$ and $5.95 \mu \mathrm{g} / \mathrm{g}$ with no significant variation while it ranged from $10.59 \mu \mathrm{g} / \mathrm{g}$ to 10.99 $\mu \mathrm{g} / \mathrm{g}$ in Katuala (D. pentaphylla) and Angili ala (D. alata) with a significant difference $(P<0.05)$. Katuala (D. pentaphylla) contained the least calcium content of $0.85 \pm 0.03 \mu \mathrm{g} / \mathrm{g}$ which was significantly different $(P<0.05)$ from those of other three yams. Copper content of Rajala (D. alata), Kukulala (D. esculenta) and Angili ala (D. alata) ranged from $2.88 \mu \mathrm{g} / \mathrm{g}$ to $4.48 \mu \mathrm{g} / \mathrm{g}$ with no significant variations. Only the content of copper $(3.81 \pm 0.03 \mu \mathrm{g} / \mathrm{g})$ in Katuala $(D$. pentaphylla) significantly $(P<0.05)$ varied from the rest. The highest manganese content $(4.42 \pm 0.10 \mu \mathrm{g} / \mathrm{g})$ was observed in Kukulala (D. esculenta) while the least manganese level $(1.81 \pm 0.79 \mu \mathrm{g} / \mathrm{g})$ was observed in Angili ala (D. alata). Nickel, cobalt, chromium, cadmium, gallium, barium, tin, selenium and arsenic were available in minor quantities in all four yams with no significant variations among species $(P<0.05)$.

Both Rajala (D. alata) and Angili ala (D. alata) which belong to the same species and variety have shown significant differences $(P<0.05)$ with regard to a number of major and minor minerals. Baah et al. (2009) reported that there were significant differences of $\mathrm{P}, \mathrm{Ca}$, $\mathrm{Mg}, \mathrm{K}, \mathrm{Na}, \mathrm{Mn}, \mathrm{Cu}$ and $\mathrm{Zn}$ contents in 16 D. alata sub varieties. 
Table 3. Mineral composition of selected yams

\begin{tabular}{|c|c|c|c|c|}
\hline $\begin{array}{c}\text { Mineral } \\
(\mu \mathrm{g} / \mathrm{g})\end{array}$ & $\begin{array}{c}\text { Rajala } \\
\text { (D. alata) }\end{array}$ & $\begin{array}{c}\text { Kukulala } \\
\text { (D. esculenta) }\end{array}$ & $\begin{array}{c}\text { Katuala } \\
\text { (D. pentaphylla) }\end{array}$ & $\begin{array}{c}\text { Angili Ala } \\
(\text { D. alata })\end{array}$ \\
\hline Potassium & $5120 \pm 0.22^{\mathrm{a}}$ & $4900 \pm 0.24^{b}$ & $4610 \pm 1.34^{\mathrm{a}}$ & $4750 \pm 0.49^{b}$ \\
\hline Magnesium & $170 \pm 0.00^{c}$ & $280 \pm 0.02^{b}$ & $250 \pm 0.02^{\mathrm{a}}$ & $210 \pm 0.02^{c}$ \\
\hline Sodium & $40 \pm 0.00^{\mathrm{a}}$ & $20 \pm 0.002^{c}$ & $30 \pm 0.003^{\mathrm{a}}$ & $260 \pm 0.001^{\mathrm{b}}$ \\
\hline Aluminium & $5.92 \pm 0.08^{\mathrm{c}}$ & $5.88 \pm 0.14^{\mathrm{c}}$ & $10.59 \pm 0.95^{\mathrm{a}}$ & $10.99 \pm 0.38^{b}$ \\
\hline Calcium & $0.52 \pm 0.11^{b}$ & $0.44 \pm 0.01^{b}$ & $0.85 \pm 0.03^{\mathrm{a}}$ & $0.51 \pm 0.07^{\mathrm{b}}$ \\
\hline Zinc & $15.95 \pm 1.25^{\mathrm{b}}$ & $15.69 \pm 0.03^{c}$ & $37.58 \pm 0.26^{\mathrm{a}}$ & $9.82 \pm 1.90^{\mathrm{b}}$ \\
\hline Copper & $4.48 \pm 0.04^{\mathrm{b}}$ & $3.61 \pm 0.009^{b}$ & $3.81 \pm 0.03^{\mathrm{a}}$ & $2.88 \pm 0.11^{\mathrm{b}}$ \\
\hline Nickel & $0.15 \pm 0.04^{\mathrm{a}}$ & $0.12 \pm 0.006^{\mathrm{a}}$ & $0.13 \pm 0.001^{\mathrm{a}}$ & $0.38 \pm 0.034^{\mathrm{a}}$ \\
\hline Cobalt & $0.04 \pm 0.01^{\mathrm{a}}$ & $0.04 \pm 0.0003^{\mathrm{a}}$ & $0.06 \pm 0.01^{\mathrm{a}}$ & $0.57 \pm 0.00^{\mathrm{a}}$ \\
\hline Iron & $23.47 \pm 0.32^{\mathrm{a}}$ & $16.80 \pm 2.96^{\mathrm{a}}$ & $26.99 \pm 1.36^{\mathrm{a}}$ & $25.63 \pm 3.44^{\mathrm{a}}$ \\
\hline Manganese & $1.98 \pm 0.25^{\mathrm{b}}$ & $4.42 \pm 0.10^{\mathrm{a}}$ & $2.39 \pm 0.14^{\mathrm{b}}$ & $1.81 \pm 0.79^{\mathrm{b}}$ \\
\hline Chromium & $0.27 \pm 0.04^{\mathrm{a}}$ & $0.13 \pm 0.02^{\mathrm{a}}$ & $0.11 \pm 0.03^{\mathrm{a}}$ & $0.28 \pm 0.008^{\mathrm{a}}$ \\
\hline Barium & $2.70 \pm 0.66^{\mathrm{c}}$ & $5.71 \pm 0.17^{\mathrm{b}}$ & $7.48 \pm 0.41^{\mathrm{a}}$ & $7.92 \pm 0.97^{\mathrm{a}}$ \\
\hline Cadmium & $0.008 \pm 0.001^{\mathrm{a}}$ & $0.01 \pm 0.004^{\mathrm{a}}$ & $0.005 \pm 0.000^{\mathrm{a}}$ & $0.005 \pm 0.000^{\mathrm{a}}$ \\
\hline Molybdenum & $0.17 \pm 0.00^{\mathrm{a}}$ & $0.76 \pm 0.00^{\mathrm{c}}$ & $0.10 \pm 0.00^{\mathrm{b}}$ & $0.04 \pm 0.01^{\mathrm{d}}$ \\
\hline Strontium & $2.26 \pm 0.21^{\mathrm{c}}$ & $2.61 \pm 0.07^{\mathrm{c}}$ & $4.5 \pm 0.27^{\mathrm{a}}$ & $3.12 \pm 0.19^{\mathrm{b}}$ \\
\hline Rubidium & $15.47 \pm 0.02^{\mathrm{b}}$ & $15.46 \pm 0.48^{b}$ & $7.58 \pm 0.75^{\mathrm{a}}$ & $8.51 \pm 0.91^{\mathrm{a}}$ \\
\hline Gallium & $0.006 \pm 0.00^{\mathrm{a}}$ & $0.01 \pm 0.001^{\mathrm{a}}$ & $0.007 \pm 0.001^{\mathrm{a}}$ & $0.01 \pm 0.001^{\mathrm{a}}$ \\
\hline Vanadium & $0.01 \pm 0.006^{\mathrm{b}}$ & $0.01 \pm 0.003^{\mathrm{b}}$ & $0.04 \pm 0.01^{\mathrm{a}}$ & $0.04 \pm 0.004^{\mathrm{a}}$ \\
\hline Beryllium & $0.0008 \pm 0.00^{\mathrm{a}}$ & $0.002 \pm 0.00^{\mathrm{a}}$ & $0.0009 \pm 0.00^{\mathrm{a}}$ & $0.001 \pm 0.00^{\mathrm{a}}$ \\
\hline Lithium & $0.06 \pm 0.009^{\mathrm{b}}$ & $0.07 \pm 0.02^{\mathrm{b}}$ & $0.06 \pm 0.01^{\mathrm{a}}$ & $0.13 \pm 0.05^{\mathrm{b}}$ \\
\hline Tin & $0.003 \pm 0.00^{\mathrm{a}}$ & $0.009 \pm 0.001^{\mathrm{a}}$ & $0.05 \pm 0.00^{\mathrm{a}}$ & $0.007 \pm 0.001^{\mathrm{a}}$ \\
\hline Selenium & $0.05 \pm 0.004^{\mathrm{a}}$ & $0.04 \pm 0.009^{\mathrm{a}}$ & $0.04 \pm 0.004^{\mathrm{a}}$ & $0.02 \pm 0.001^{\mathrm{a}}$ \\
\hline Arsenic & $0.001 \pm 0.000^{\mathrm{a}}$ & $0.001 \pm 0.000^{\mathrm{a}}$ & $0.005 \pm 0.00^{\mathrm{a}}$ & $0.005 \pm 0.000^{\mathrm{a}}$ \\
\hline
\end{tabular}

Data represent the mean of three replicates fresh weight basis. Values followed by the different superscript in each row are significantly different $(P<0.05)$.

Mineral content in the soil may have affected the mineral content of yams studied. Mineral contents analyzed varied from mineral level reported by Senanayake et al. (2012). This was due to the samples represented all the agro-climatic zones in Sri Lanka. Therefore, each sample was a composite sample of number of different samples obtained from different cropping systems under different agronomic practices (Senanayake et al., 2012).

Potassium is a mineral that helps the kidneys to function normally and control blood pressure. With this appreciable content of potassium in the varieties, D. alata could be recommended for people with high blood pressure (Baah et al, 2009). Sodium is important for the control of water balance in the body. It also helps with normal nerve impulse regulation and muscle contraction. The recommended daily intake of $\mathrm{Na}$ is between $1110 \mathrm{mg}$ and $3300 \mathrm{~m}$. However, too much of sodium can be harmful to the body (Walsh, 2003). The high potassium and comparatively low sodium contents were found in tested yams. Walsh (2003) has explained that the varieties with high potassium and low sodium may make them have a good potassium-sodium balance in the human body thus protect against osteoporosis and heart diseases.

WHO (2011) shows that the mean daily intake of arsenic in food for adults has estimated to range from $16.7 \mu \mathrm{g}$ to $129 \mu \mathrm{g}$. The $\mathrm{LD}_{50}$ value of arsenic is $15 \mathrm{mg} / \mathrm{Kg}$ according to LHS Living By Chemistry (2004). Lethal dosage of arsenic for human is $3 \mathrm{~g} / \mathrm{Kg}$ (Agency for Toxic 
Substances and Disease Registry, 2010). According to the results generated, all the yams analyzed contained below $0.005 \mu \mathrm{g}$ of As which was 600,000 times minor than the harmful limit.

\section{CONCLUSIONS}

Significant intra-species differences and inter-species differences were observed in proximate composition and mineral contents of yams studied. High quantities of carbohydrate and energy with appreciable levels of minerals make the yams nutritious and can be used as reliable food and energy security crop. Yams studied were poor in proteins (1$2 \%$ ) so that it is essential to combine with protein sources to make it wholesome. The most predominant minerals in these yams were $\mathrm{K}, \mathrm{Mg}, \mathrm{Na}, \mathrm{Zn}$ and $\mathrm{Fe}$. Some clear significant differences were observed among different accessions of the same species with regard to crude fat, crude protein, ash and most of the mineral contents.

\section{ACKNOWLEDGEMENT}

The authors express their gratitude to Department of Geology of Faculty of Science of University of Peradeniya, Sri Lanka. Special thanks also go to the United Nations Environment Program and Food and Agriculture Organization of United Nations for funding and Plant Genetic Resource Center, Department of Agriculture, Sri Lanka for supplying the yam samples.

\section{REFERENCES}

Afoakwa, E.O. and Sefa-Dedeh., S. (2001). Chemical composition and quality changes occurring in Dioscorea dumetorum pax tubers after harvest. Food Chem. 75, 85-91.

Agbor-Egbe, T. and Treche, S. (1995). Evaluation of the chemical composition of Cameroonian yam germplasm. J. Food Comp. Anal. 8, 274-283.

Agency for Toxic Substances and Disease Registry, (2010). Arsenic Toxicity Case Study: Clinical Assessment | ATSDR - Environmental Medicine \& Environmental Health Education -CSEM. [on line]. [Accessed on 30.04.2017]. Available at http://www.atsdr.cdc.gov/csem/csem.asp?csem=1\&po=12.

AOAC (2000). Official Methods of Analysis. Association of Official. Analytical Chemists, Washington, D.C., USA.

Baah, F.D., Dixon, B.M., Bobert, A.and Oduro, I. (2009). Nutritional and biochemical composition of D. alata ( Dioscorea spp .) tubers. J. Food Agric. and Environ. 7(2), 373-378.

Bartkiene, E., Juodeikiene, G. and Basinskiene, L. (2012). In vitro fermentative production of plant lignans from cereal products in relationship with constituents of non-starch polysaccharides. Food Sci. Biotechnol. 50(2), 237-245.

Bhandari, M.R., Kasai, T. and Kawabata, J. (2003). Nutritional evaluation of wild edible yam (Dioscorea sp.) tubers of Nepal. Food Chem. 82 (4), 619-623. 
Hongxing, Z. and Yu-kui, R. (2012). Determining mineral elements in four kinds of grains from Beijing market by ICP-MS simultaneously. J. Saudi Chem. Soc. 16(1), 31-33. Available at: http://dx.doi.org/10.1016/j.jscs.2010.10.014.

Jayakody, L., Hoover, R., Liu, Q. and Donner, E. (2007). Studies on tuber starches. II. Molecular structure, composition and physicochemical properties of yam (Dioscorea sp.) starches grown in Sri Lanka, Carbohydr. Polym. 69, 148-163.

Jayasuriya, A.H.M. (1995) Dioscoreaceae .9, 47 -80.In: M.D.Dissanayake (Ed), A revised handbook to the flora of Ceylon, Sri Lanka.

Knoth, J. (1993). Traditional storage of yams and cassava and its improvement. GTZ, Germany.

Lebot, V., Malapa, R., Molisale, T. and Marchand, J.L. (2005). Physicochemical characterization of yam (Dioscorea alata L.) tubers from Vanuatu. Genet. Resour. Crop Evol. 53(6), 1199-1208.

LHS Living By Chemistry (2004). Lethal Dose Table [on line]. [Accessed on 30.07.2017]. Available at: http://whs.rocklinusd.org/documents/Science/Lethal_Dose_Table.pdf

Moorthy, S.N., (1994): Tuber Crops Starches. Central Tuber Crops Research Institute.Technical Bulletin Series:18: 40. St Josephs Press, Cotton Hill, Thiruwanathapuram, Kerala, India.

Osagie, A.U. (1992).The Yam Tuber in Storage. Post-harvest Research Unit, University of Benin, Nigeria. pp.107 - 173.

Polycarp, D., Afoakwa, E.O., Budu, A.S. and Otoo, E. (2012). Characterization of chemical composition and anti-nutritional factors in seven species within the Ghanaian yam (Dioscorea) germplasm. Int. Food Res. J. 19(3), 985-992.

Punyawardena, B.V.R., Bandara, T.M.J., Munasinghe, M.A.K. and Bandara, N. J. (2003). Agro ecological regions of Sri Lanka. Natural Resource Management Centre, Department of Agriculture, Peradeniya, Sri Lanka.

Ray, R.C. and Sivakumar, P.S. (2009). Traditional and novel fermented foods and beverages from tropical root and tuber crops: review. Int. J. Food Sci. \& Tech. 44 (6), 1073-1087.

Sangakkara, R. and Frossard, E. (2014). Home gardens and Dioscorea species - A case study from the climatic zones of Sri Lanka. J. Agr. Rural Dev. Trop. 115(1), 55-65.

Senanayake, S.A., Ranaweera, K.K.D.S., Bamunuarachchi, A. and Gunarathne, A. (2012). Proximate Analysis and Phytochemical and Mineral Constituents in Four Cultivars of Yams and Tuber Crops in Sri Lanka. Trop. Agr. Res. \& Exten. 15(1).

Shanthakumari, S., Mohan, V.R. and John de Britto. (2008). Nutritional Evaluation and Elimination of Toxic Principles in Wild Yam (Dioscorea spp.), Trop. Subtrop. Agrosys. 8, 319-325. 
Walsh, S. (2003). Plant Based Nutrition and Health. Vegan Society Ltd, London. 54, 165166.

WHO, (2004). Arsenic in drinking-water. Arsenic in Drinking-water. 84, 41-267.

Ying, B., Liu, L. and Ji, R. (2007). Determination of eight elements in grain and vegetable by microwave digestion-ICP-MS. Journal of Hygiene Research, 36(4), 495-7.

Yu, S. and Izidorczyk, M. S. (2002). Molecular characteristics of barley starches with variable amylose content. Carbohydr. Polym. 49, 33-42. 